\title{
Effect of Electro Slag Remelting (ESR) on the microstructure and mechanical properties of low carbon bainitic steel
}

\author{
E. Entezari ${ }^{1}$, B. Avishan ${ }^{2}$, H. Mousalou ${ }^{1}$, S. Yazdani ${ }^{1 *}$ \\ ${ }^{1}$ Faculty of Materials Engineering, Sahand University of Technology, Tabriz, Iran \\ ${ }^{2}$ Department of Materials Engineering, Azarbaijan Shahid Madani University, Tabriz, Iran
}

Received 28 February 2018, received in revised form 22 May 2018, accepted 2 July 2018

\begin{abstract}
It is essential to produce steels free from impurities and inclusions and decrease the segregations as much as possible knowing that the quality of the primary cast steel is a very critical factor influencing its final microstructure and mechanical properties. For this aim, various refinement processes including Electro Slag Remelting (ESR) have been developed to gain high-quality primary steel for subsequent heat treatments and production procedures. This article aims to study the effect of primarily conducted ESR process on microstructural characteristics and final mechanical properties of carbide free low carbon bainitic steels isothermally obtained at 350 and $400^{\circ} \mathrm{C}$. Results indicated that applying the ESR process before the austempering heat treatments was beneficial in steel refinement and production of a clean product free from inclusions. Besides, it has been declared that the amount of the segregation in heat treated material decreased after conducting the ESR process and a much more uniform distribution of alloying elements within the primary austenite could be attained. Uniform primary austenite resulted in finer bainitic ferrites, much more uniform size distribution of bainitic subunits and higher volume fraction of high carbon retained austenite. Finally, it has been shown that higher values of ultimate tensile strength in combination with enhanced elongation and also improved impact toughness properties could be achieved in samples primarily electro-slag remelted.
\end{abstract}

K e y w o r d s: Electro Slag Remelting (ESR), low carbon steel, bainite, microstructure, mechanical properties

\section{Introduction}

The development of the steel industry has increased the demand for high-quality products. In this regard, Electro Slag Remelting (ESR) process has been exploited as one of the most important methods to enhance the quality of primary cast steels and consequently to increase the quality of the final material. ESR is based on converting electrical energy into thermal energy by transferring electrical current through a slag layer with proper chemical composition and appropriate physical properties. The main cause of heat production in the ESR process is the electrical resistance of the slag against the electric current, which leads to the remelting of steel $[1-3]$. The inclusions and impurities are significant factors reducing the final mechanical properties of steels $[4,5]$ and other alloys
[6]. Utilizing the ESR process would lead to the decline and elimination of inclusions and segregations successfully $[7,8]$. In this regard, the kind of slag being used and also electrode variables [9] would have a significant role in the final quality of the remelted steel. For instance, it has been demonstrated that [10], slag with a proper chemical composition of $\mathrm{CaO}, \mathrm{Al}_{2} \mathrm{O}_{3}, \mathrm{MgO}$, $\mathrm{SiO}_{2}$, and $\mathrm{CaF}_{2}$ had a detrimental impact on the number of impurities. Considering the ESR procedure and its theoretical aspects, the water jacket and copper plates surrounding the crucible in ESR furnace would result in the reduction of local solidification time $[1$, $2,4,5,11]$ which in turn would decrease the interdendritic spacing, and consequently would decrease the segregation [12]. Similarly, the ESR process would affect the resultant mechanical properties as it has been demonstrated in some studies before. For exam-

*Corresponding author: e-mail address: Yazdani@sut.ac.ir 
Table 1. The chemical composition of remelted and non-remelted samples (wt.\%)

\begin{tabular}{lcccccccccccc}
\hline Composition & $\mathrm{S}$ & $\mathrm{P}$ & $\mathrm{Al}$ & $\mathrm{V}$ & $\mathrm{Cu}$ & $\mathrm{Mo}$ & $\mathrm{Ni}$ & $\mathrm{Cr}$ & $\mathrm{Mn}$ & $\mathrm{Si}$ & $\mathrm{C}$ \\
\hline Non-remelted & 0.030 & 0.029 & 0.047 & 0.13 & 0.98 & 0.25 & 1.19 & 1.1 & 1.58 & 1.45 & 0.244 \\
Remelted & 0.012 & 0.027 & 0.047 & 0.13 & 0.98 & 0.25 & 1.19 & 1.1 & 1.31 & 1.04 & 0.241 \\
\hline
\end{tabular}

ple, Pribulova et al. [13] demonstrated that enhanced tensile strength and elongation could be achieved after conducting the ESR process on STN14109 steel compared to that obtained before ESR treatment. In another study, Qi et al. [14] claimed that directional solidification after conducting the ESR process resulted in the elimination of macrosegregation and decreased the secondary dendrite arm spacing which gave rise to an enhanced strength of austenitic hot-work die steel. $\mathrm{Fu}$ et al. [15] showed that removing the defects such as shrinkage voids and segregations from superalloy Rene88DT through the ESR refined-continuous directional solidification (ESR-CDS) improved the resultant mechanical properties. Hebsur et al. [16] demonstrated that performing the ESR remelting process resulted in the improvement of elongation and fracture toughness and led to a decrease in fatigue crack propagation rate in AISI 4340 steel. Also, Pacyna et al. [17] suggested that the fracture toughness of H13 steel successfully enhanced due to the removal of non-metallic inclusions after the ESR process.

Despite all studies on certain iron base alloys, it is useful to be aware that a wide range of mechanical properties would be achieved by conducting a suitable heat treatment process on different steel types. For instance, applying a low-temperature austempering heat treatment would result in a unique bainitic microstructure consisting of very fine bainitic ferrites and high carbon retained austenite. Known as low-temperature bainite, these groups of bainitic steels give exceptional mechanical properties which have been reported previously in different studies [18-22]. However, it is critical to be aware of the significance of producing clean steel before conducting the isothermal bainite heat treatment if desirable mechanical properties are demanded. However, there is lack of data on the effect of ESR process on the microstructure and mechanical properties of low-temperature bainitic steels. Even if the expectation is, the lack of impurities and the lowest amount of inclusions and lower segregation will lead to enhanced mechanical properties and consequently more beneficial and appropriate industrial applications of those materials. That is the reason why in many different previous studies a primary ESR process was implemented on the cast steel before the bainitic heat treatment [23-26]. Accordingly, this work aims to investigate how the ESR process affects the microstructural characteristics and resultant mechanical properties in low carbon bainitic steels obtained after austempering at 350 and $400{ }^{\circ} \mathrm{C}$.

\section{Materials and methods}

The primary ingot was cast using an induction furnace under an inert gas atmosphere with a $10 \mathrm{~kg}$ capacity. A metal mould was used for casting, and consequently, the ERS process was performed to obtain steel with a minimum amount of inclusions and impurities within the material. The ESR process was carried out at the voltage range of $23-25 \mathrm{~V}$, current intensity of almost 140 to $180 \mathrm{~A}$ with slag composition of $\% 70 \mathrm{Al}_{2} \mathrm{O}_{3+} \% 30 \mathrm{CaF}_{2}$. Iron chips were used to create the initial spark and start the remelting process. The final chemical composition of the material after conducting the ESR process is given in Table 1.

Steel was hot rolled to a sheet of almost $17 \mathrm{~mm}$ thickness at a temperature range of $900-1000{ }^{\circ} \mathrm{C}$. To achieve the bainitic microstructure, the hot rolled sheet was primarily homogenized at $1200^{\circ} \mathrm{C}$ for $4 \mathrm{~h}$ and consequently, samples were cut and machined from hot rolled sheets and isothermally heat treated at two different temperatures of 350 and $400^{\circ} \mathrm{C}$ immediately after austenitizing at $900^{\circ} \mathrm{C}$ for $30 \mathrm{~min}$. Samples were quenched in $25^{\circ} \mathrm{C}$ water at the end of the bainite transformation. The $65 \mathrm{~min}$ of austempering time has been selected as the optimum heat treatment time according to kinetics evaluations at the end of which the maximum volume fraction of bainite and retained austenite could be attained which consequently would result in optimum comprehensive mechanical properties. Figure 1 schematically summarizes the heat treatment process.

Primary microstructural evaluations were performed using OLYMPUS PMG3 ${ }^{\mathrm{TM}}$ optical microscope (OM) after grinding, polishing and etching the samples according to the standard procedures. More precise microstructural studies were conducted on Cam Scan MV 2300 ${ }^{\mathrm{TM}}$ scanning electronic microscope (SEM), and EDX analyses were carried out on the same SEM instrument when needed. X-ray diffraction was used to determine the volume fraction of high carbon retained austenite within the microstructure using a BRUKER-AXS D8 ${ }^{\mathrm{TM}}$ diffractometer. XRD samples were etched and polished for several times to remove the deformed layer, and the austenite content was measured using the integrated intensities of (200), (220) and (311) peaks of austenite and (200), (211) 


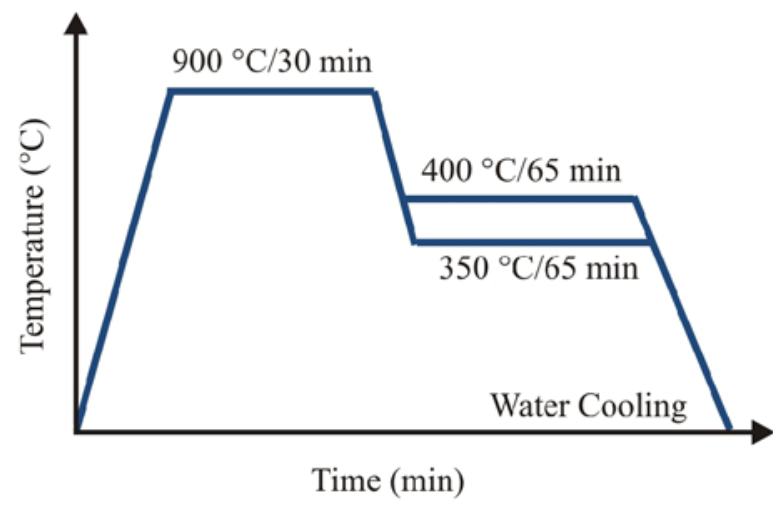

Fig. 1. Schematic illustration of the bainite heat treatment procedure.

and (220) peaks of ferrite [27]. XRD tests were carried out in $2 \theta$ range of $40-101^{\circ}$ with monochromatic $\mathrm{CuK} \alpha$ radiation.

High magnification SEM pictures were used to determine the thicknesses of the bainitic subunits using the line intercept method [28, 29]; at least 80 measurements were performed on 10 different images at different magnifications from different regions of the samples, and the average values have been reported.

Tensile tests were conducted on samples that were cut along the rolling direction according to JIS Z2201 standard. At least 3 tensile specimens were used in each experiment to ensure the reproducibility and all tests were carried out at ambient temperature. Charpy impact tests were performed on a standard Roell Amsler ${ }^{\mathrm{TM}}$ testing machine by using notched samples of $10 \times 10 \times 55 \mathrm{~mm}^{3}$ dimensions at room temperature. At least 5 tests were performed, and reported values were the average of at least 3 measurements. Finally, microhardness tests were carried out using a $100 \mathrm{~g}$ load when it was needed.

\section{Results and discussion}

Figure 2 elucidates the Time-Transformation-Temperature (TTT) diagram and the variations of the bainitic transformation driving forces obtained using MUCG83 thermodynamic model [30]. The model has been designed based on thermodynamic theories, and it is capable of predicting some thermodynamic aspects of bainitic transformation and martensite start temperature (Ms) of the designed steel [31].

It can be seen that the TTT diagram composed of two upper and lower C-shape curves in which the former gives information on reconstructive solid-state transformation kinetics and the latter predicts the kinetics of the shear transformations, e.g., bainite transformation. According to the TTT diagram, steel had enough hardenability to avoid ferrite and perlite for-
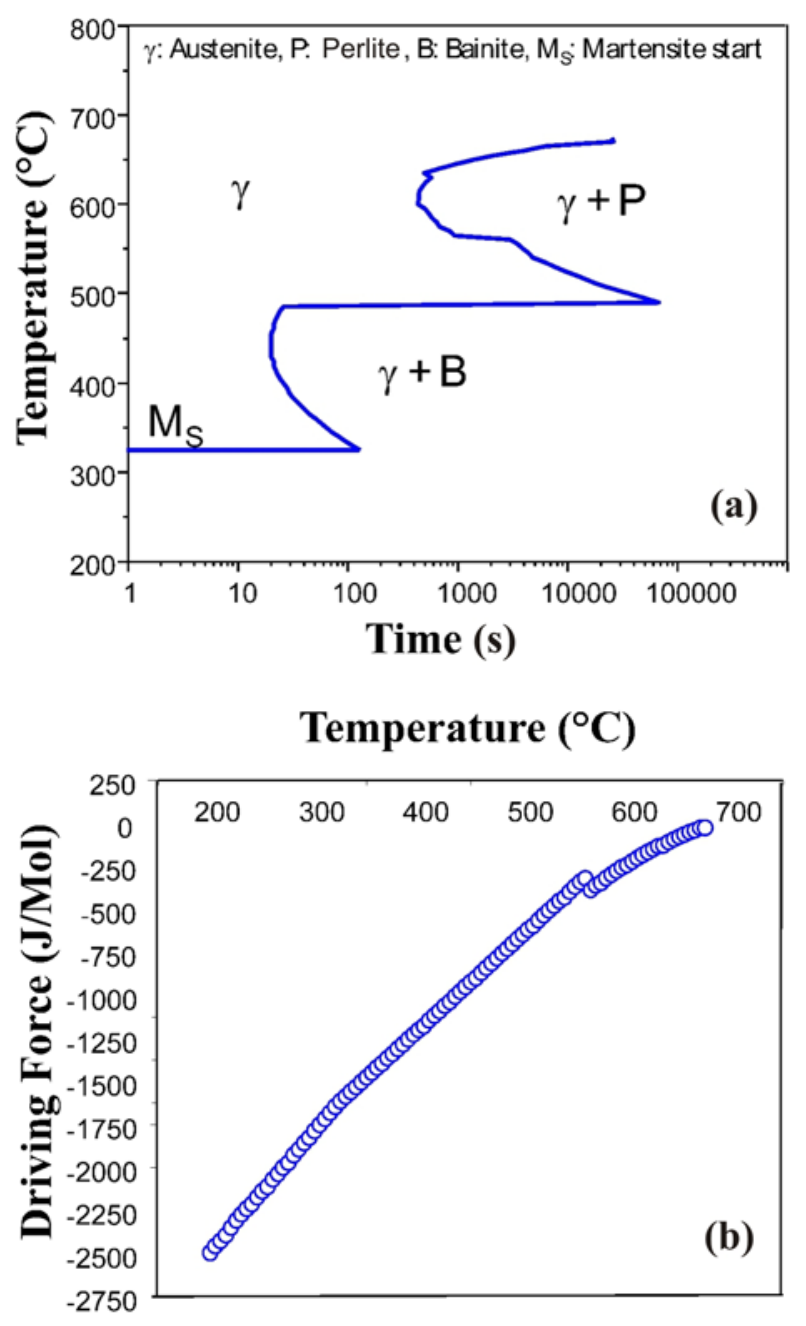

Fig. 2. The results obtained from MUCG83 software for the studied steel: (a) TTT diagram indicating perlite, bainite transformation regions and martensite start temperature and (b) driving force vs. temperature.

mation while quenching the samples from austenitizing to austempering furnaces. Moreover, it can be seen that the time needed for the start of bainite transformation was dependent on isothermal bainite transformation temperature being higher at lower austempering temperatures. On the other hand, the driving force of the bainitic transformation was dependent on the bainite start temperature and decreasing the transformation temperature increases the driving force of the bainite formation which in turn would affect the volume fraction and size of the microstructural constituents.

Figure 3 depicts the OM pictures of ESR and nonESR samples after conducting the bainite transformation at 350 and $400^{\circ} \mathrm{C}$. According to the pictures, the resulting microstructures consisted of bainitic sheaves embedded in light regions of high carbon retained austenite or martensite. It can be seen that, higher 

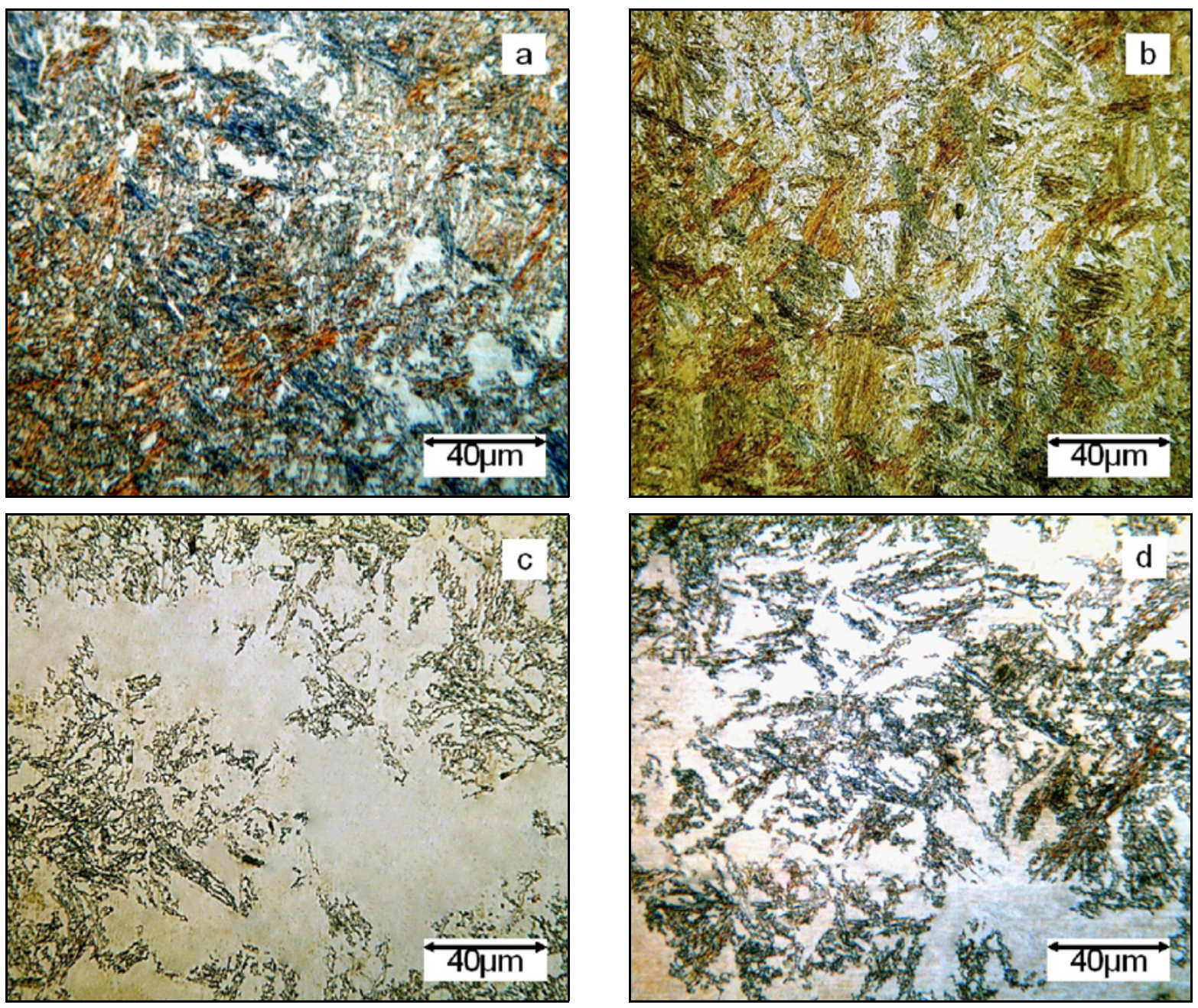

Fig. 3. Optical microscopy images of the studied SAMPLES austempered at (a) $350^{\circ} \mathrm{C}$ without ESR, (b) $350^{\circ} \mathrm{C}$ after ESR, (c) $400^{\circ} \mathrm{C}$ without ESR, and (d) $400^{\circ} \mathrm{C}$ after ESR.

volume fractions of bainite formed at lower transformation temperature in both ESR and non-ESR samples which can be directly related to the higher driving force of bainitic transformation at lower austempering temperatures as it has been shown in Fig. 2 b. Bainitic transformation starts by paraequilibrium nucleation of bainitic ferrites and progresses with their shear growth. Only carbon partitions from ferrite to surrounding austenite during the process and carbon remains in solid solution due to enough amount of silicon were added to the chemical composition. High carbon content within the austenite decreases its Ms temperature and therefore stabilizes this phase at room temperature. According to the figures, bainitic sheaves aligned in different crystallographic directions are separated with austenite or martensite micro blocks.

Austenite phase can be categorized in two different morphologies at the end of the bainite transformation. First is the filmy austenites within bainitic sheave and the second is austenite micro blocks which separate sheaves of bainite. The latter is thermally and mechan- ically less stable due to its lower carbon content especially in center regions $[32,33]$. Higher volume fractions of austenite blocks would be present within the microstructure at higher transformation temperature due to the lower content of bainite. However, more bainite transformation at lower austempering temperatures, in turn, consumes more primary austenite. Therefore, higher bainitic sheaves volume form and this ends in a higher content of austenite film and fewer austenite blocks within the matrix. It has been shown that it is critical to replace austenite blocks with austenite films as much as possible if the best comprehensive mechanical properties are demanded $[34,35]$. It was impossible to distinguish the sizes and features of austenite films and bainitic ferrite plates within bainitic sheaves using the OM pictures. So, high magnification SEM pictures were used to characterize and measure the thicknesses of the microstructural constituents in different samples results of which are shown in Fig. 4. It can be seen that alternate layers of dark bainitic ferrites and lighter austenite films 

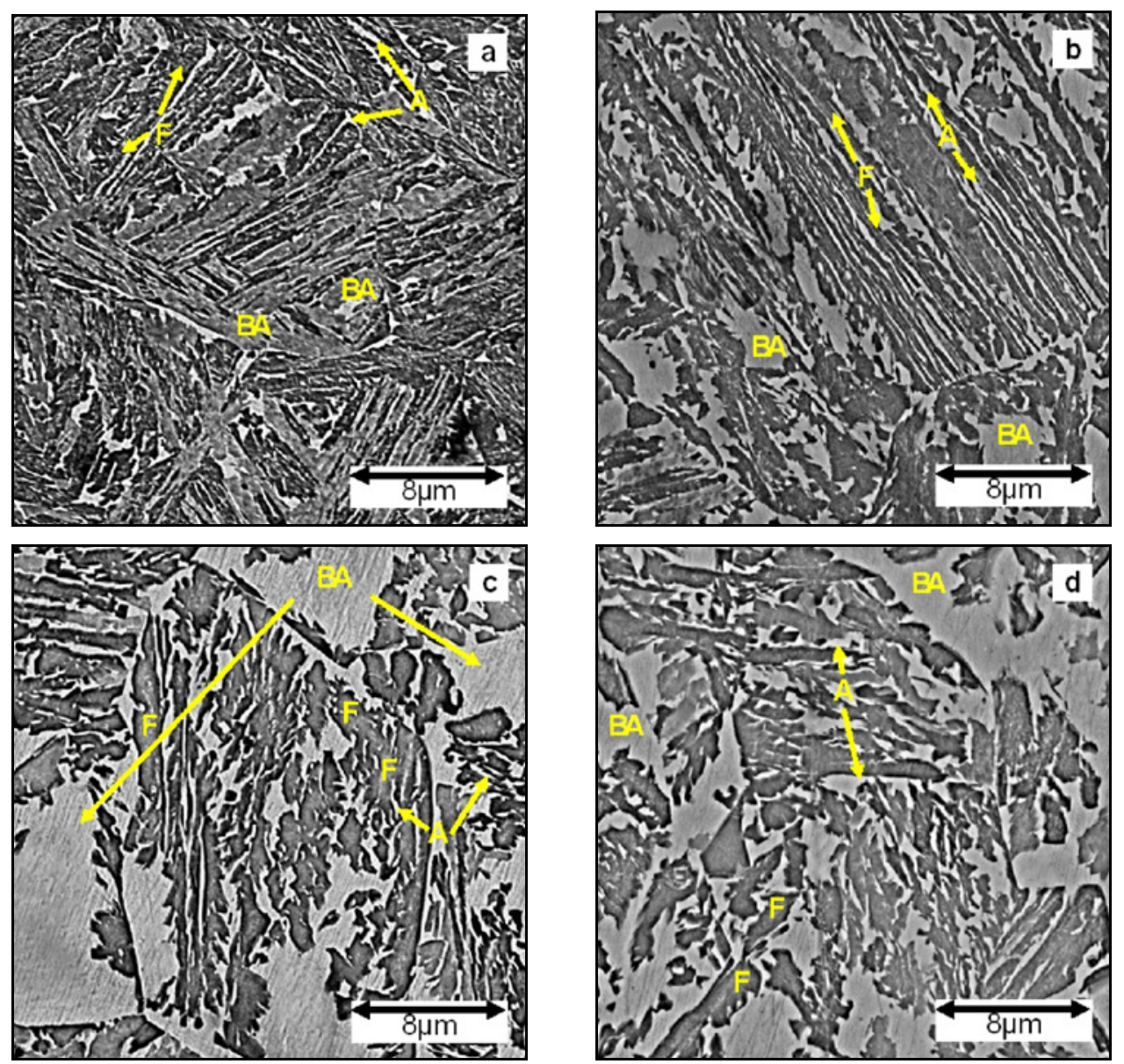

Fig. 4. The scanning electron microscope images of the studied steel samples austempered at (a) $350{ }^{\circ} \mathrm{C}$ without ESR, (b) $350{ }^{\circ} \mathrm{C}$ after ESR, (c) $400^{\circ} \mathrm{C}$ without ESR, and (d) $400{ }^{\circ} \mathrm{C}$ after ESR, where A, F, and BA represent filmy austenite, bainitic ferrite and blocky austenite respectively.

Table 2. The results obtained from the thickness measurement of ferrite sheaves

\begin{tabular}{lc}
\hline Sample & Average thickness of bainitic-ferrite subunits $(\mu \mathrm{m})$ \\
\hline Austempered at $350^{\circ} \mathrm{C}$ without ESR & 0.190 \\
Austempered at $350^{\circ} \mathrm{C}$ after ESR & 0.169 \\
Austempered at $400^{\circ} \mathrm{C}$ without ESR & 0.288 \\
Austempered at $400^{\circ} \mathrm{C}$ after ESR & 0.272 \\
\hline
\end{tabular}

were aligned in the same crystallographic directions within each bainitic sheaf.

Table 2 summarizes the effect of transformation temperature and production method on the thickness of the bainitic ferrites and their size distributions which is also illustrated in Fig. 5. According to the table, thinner bainitic ferrites were achieved at $350{ }^{\circ} \mathrm{C}$ comparing to that of $400^{\circ} \mathrm{C}$. Moreover, results indicated that conducting the ESR process, decreased the ferrite plate thicknesses. It must be mentioned that austenite films had almost identical thicknesses to those of bainitic ferrites and a similar trend was spotted in a change of the thicknesses of the austen- ite films. Moreover, Fig. 5 demonstrated that a much uniform size distribution could be obtained by conducting the ESR process in samples austempered at both 350 and $400{ }^{\circ} \mathrm{C}$.

Different parameters affect the thickness of the microstructural constituents in carbide free bainitic steels. Among those, the austenite strength is the most important one which must be taken into account. Stronger austenite more restricts the motion of the glissile interface of bainitic ferrite plate and surrounding austenite and results in a finer microstructure. So it was not strange to gain finer bainitic ferrites at lower transformation temperature since the austenite was 


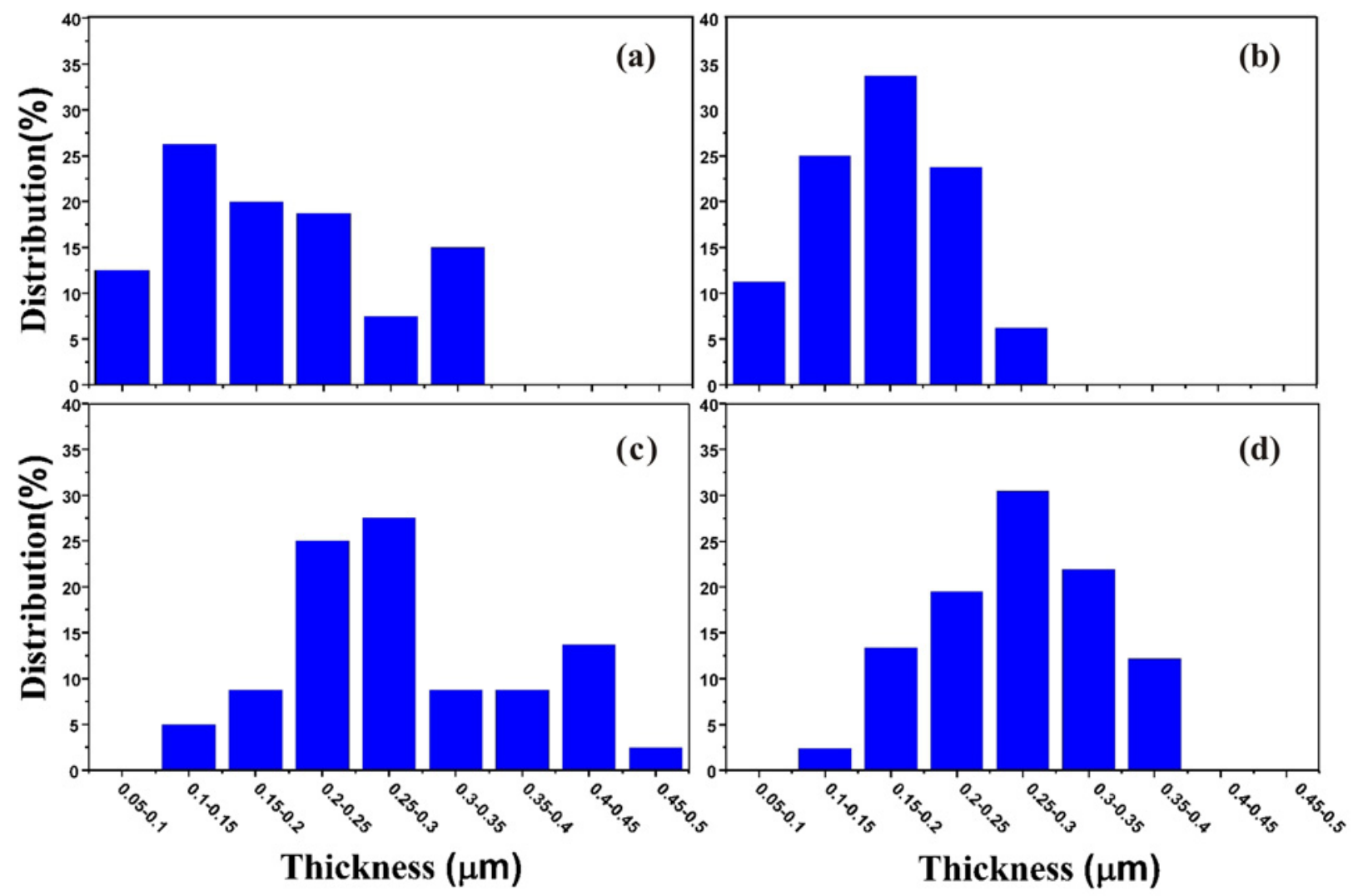

Fig. 5. Distribution of the size of bainitic ferrite subunits in samples austempered at (a) $350{ }^{\circ} \mathrm{C}$ without ESR, (b) $350{ }^{\circ} \mathrm{C}$ after ESR, (c) $400^{\circ} \mathrm{C}$ without ESR, and (d) $400^{\circ} \mathrm{C}$ after ESR.

much stronger at these temperature ranges. On the other hand, care must be taken to the point that, higher driving force of bainite nucleation and consequently higher volume fraction of bainite resulted in more severe impingement of bainitic subunits and therefore restricted their growth. As a result, thinner bainitic ferrites were achieved.

The lower average thickness of the bainitic ferrite plates in ESR samples comparing to that of non-ESR samples can be related to the nature of the ESR process. The ESR process reduces segregation of the alloying elements throughout the samples as the reduction of inclusions and impurities which is also pointed out in other studies $[2,12]$. Low segregation degree of alloying elements and their more uniform distribution after ESR process directly affected the strength of austenite and led to a uniform distribution of austenite strength throughout the microstructure. Based on the fact that ESR process also evidently decreases the local solidification time due to the nature of the process and the type of mould used for remelting and solidifying the steel, it is not strange to gain finer microstructural features in ESR samples.

Precise OM and SEM microstructural assessments demonstrated no inclusions were found within the microstructure of samples after ESR, but some were present within the microstructure of the non-ESR
Ta ble 3. The austenite volume fraction for studied samples

Sample

Austenite volume (\%)

Austempered at $350^{\circ} \mathrm{C}$ without ESR

Austempered at $350^{\circ} \mathrm{C}$ after ESR

Austempered at $400^{\circ} \mathrm{C}$ without ESR

$8.95 \pm 3$

Austempered at $400^{\circ} \mathrm{C}$ after ESR

$16 \pm 3$

$<5$

$5 \pm 3$

samples. The inclusions were almost eliminated by conducting the ESR process or at least their volume fractions were extremely lower compared to that of non-ESR state. Examples of these inclusions are shown in Fig. 6 which was revealed to be $\mathrm{Al}_{2} \mathrm{O}_{3}$ particles according to corresponding EDX analysis.

Table 3 summarizes the results of the XRD profile refinements in ESR and non-ESR samples after austempering at 350 and $400^{\circ} \mathrm{C}$. According to the results, austempering at $350^{\circ} \mathrm{C}$ resulted in a higher volume fraction of high carbon austenite compared to that of $400^{\circ} \mathrm{C}$ in both ESR and non-ESR samples. Moreover, results indicated that conducting the ESR process in both samples increased the amount of the austenite phase being stable within the microstructure at room temperature. 
Table 4. The tensile properties of non-ESR and ESR processed samples at each bainitic heat treatment

\begin{tabular}{lcc}
\hline Sample & Tensile strength (MPa) & Total elongation (\%) \\
\hline Austempered at $350^{\circ} \mathrm{C}$ without ESR & 1315 & 14 \\
Austempered at $350^{\circ} \mathrm{C}$ after ESR & 1380 & 16 \\
Austempered at $400^{\circ} \mathrm{C}$ without ESR & 1500 & 5 \\
Austempered at $400^{\circ} \mathrm{C}$ after ESR & 1600 & 7 \\
\hline
\end{tabular}

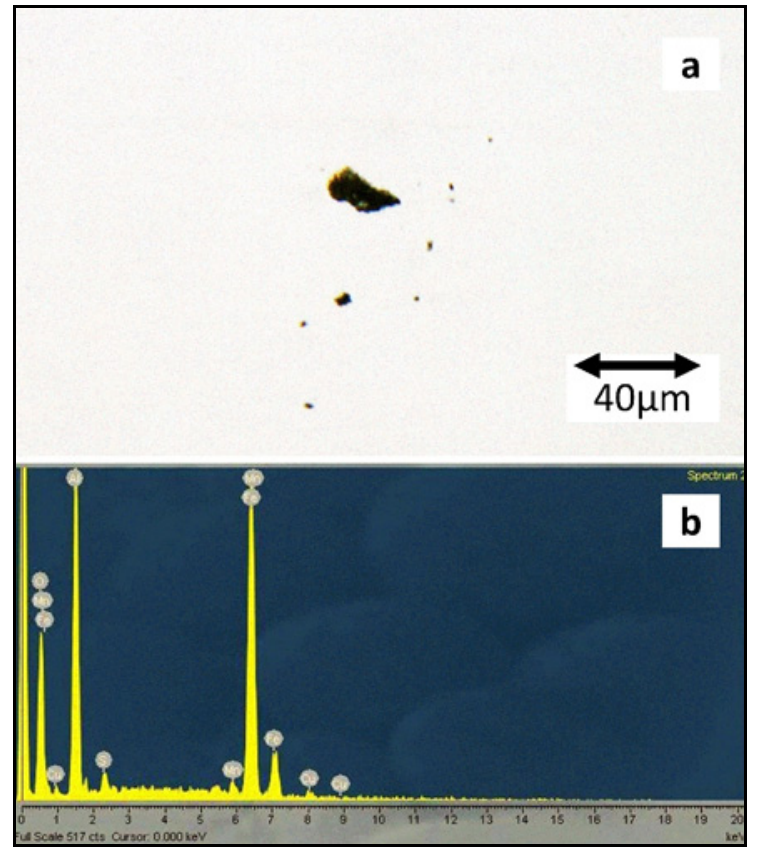

Fig. 6. Example of (a) OM image of Al2O3 inclusions in the non-ESR sample and (b) corresponding EDS analysis.

Theoretically, it was expected to gain a higher volume fraction of retained austenite after isothermal bainite heat treatment at a higher temperature of $400^{\circ} \mathrm{C}$. However, care must be taken to the point that the volume fraction of the bainite formed at $400{ }^{\circ} \mathrm{C}$ was lower than that of the austempering temperature at $350^{\circ} \mathrm{C}$. The lower volume fraction of bainite resulted in lower carbon rejection to surrounding austenite, and consequently, it would not be enough enriched with carbon to be stable at room temperature. As a result, much of the austenite transformed to martensite during cooling to room temperature after bainite transformation and less austenite became stable. The microstructure consisted of bainitic ferrites, some austenite and high volume fraction of martensite. This was also confirmed by hardness measurements which are given in Fig. 7 . According to the Figure, samples were much harder at the end of the austempering heat treatment at $400^{\circ} \mathrm{C}$ in both ESR and non-ESR samples due to their higher volume fraction of martensite and lower content of high carbon retained austenite.

Conducting the ESR also increased the amount of

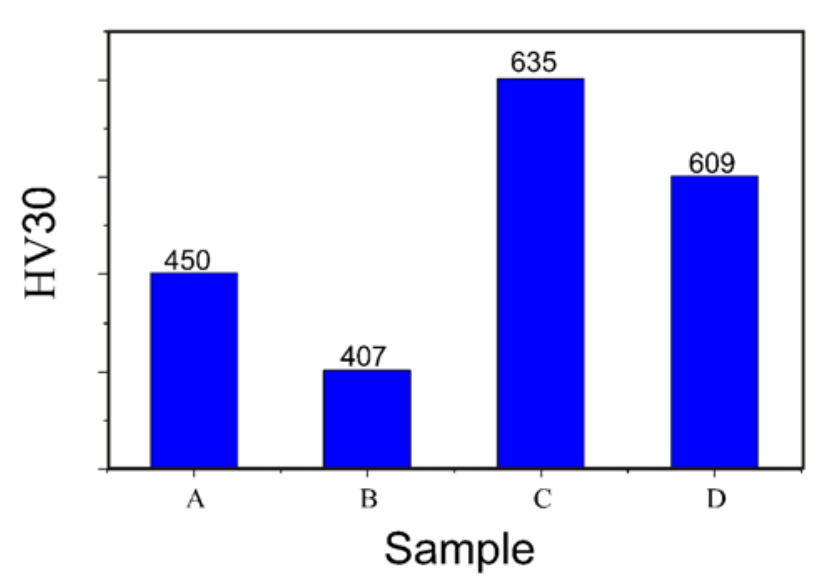

Fig. 7. Micro-hardness of samples austempered at $350^{\circ} \mathrm{C}$ (A: without ESR), $350^{\circ} \mathrm{C}$ (B: after ESR), $400^{\circ} \mathrm{C}$ (C: without ESR) and $400^{\circ} \mathrm{C}$ (D: after ESR).

austenite and higher contents have been measured in both ESR, and non-ESR samples heat treated at 350 and $400^{\circ} \mathrm{C}$. It seems that this can be associated with the changes in segregation degree and volume fraction of inclusions within the microstructure. Lower segregation degree and uniform distribution of elements in the matrix resulted in the stability of austenite from point to point, and therefore improved thermal stability achieved within the matrix. The higher volume fraction of austenite resulted in lower hardness in ESR samples as it can be seen in Fig. 7.

Changes in microstructural characteristics would directly influence the strength and ductility properties. Quantitative data extracted from the tensile test results are summarized in Table 4 . It is evident that changing the austempering temperature and conducting the ESR process both influenced the strength and ductility properties. Samples austempered at $400^{\circ} \mathrm{C}$ gave higher UTS and lower elongation values in both ESR and non-ESR status comparing to those obtained after austempering at $350^{\circ} \mathrm{C}$. Moreover, results indicated that the strength and elongation values both enhanced by conducting the ESR process at each transformation temperature. This means that performing a primary ESR process before conducting the bainitic heat treatment could successfully enhance the comprehensive mechanical properties.

Change in strength properties can be rationalized knowing that, the volume fraction and thickness of 

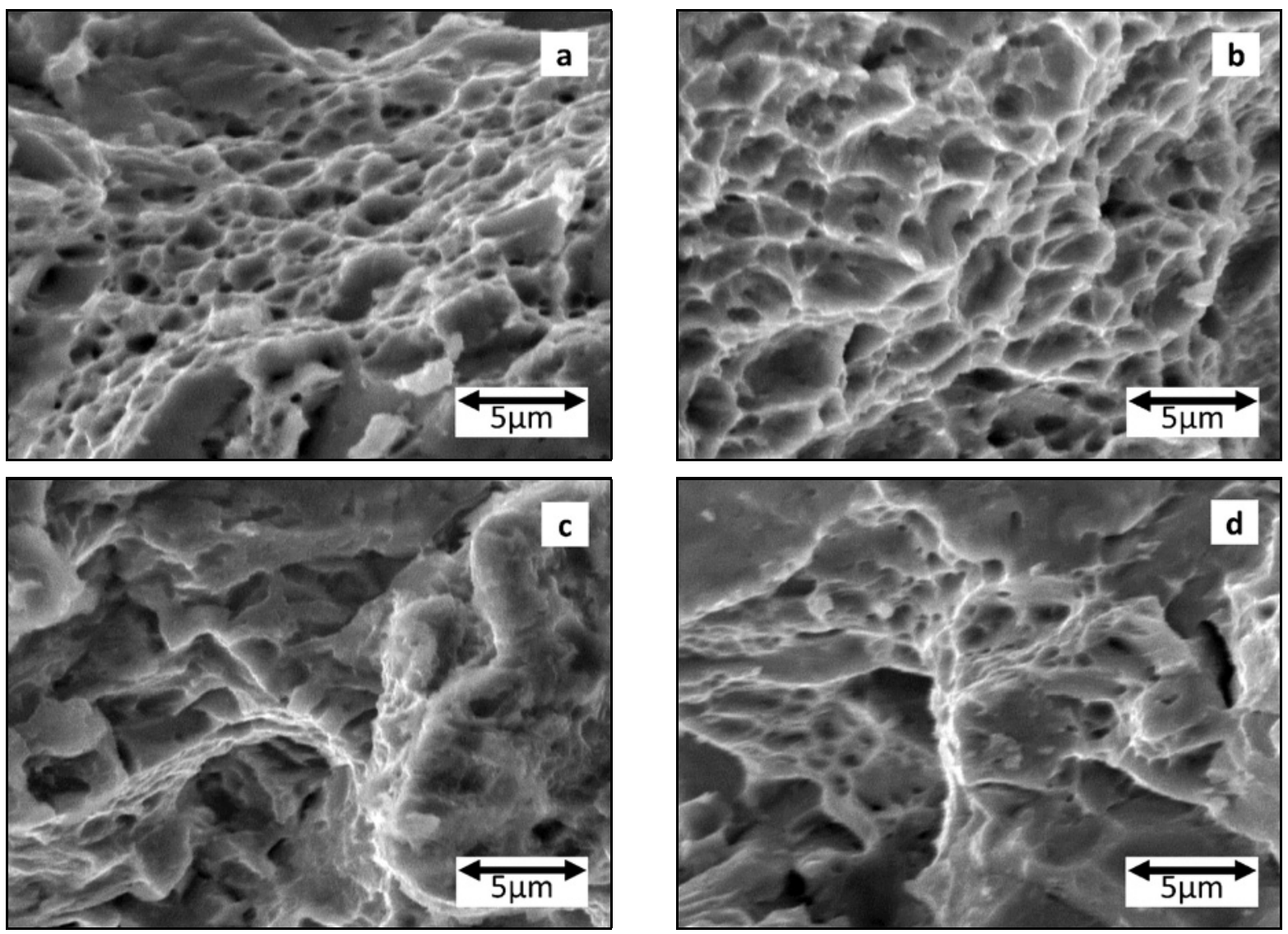

Fig. 8. The fracture surface of tensile test specimens austempered at (a) $350^{\circ} \mathrm{C}$ without ESR, (b) $350^{\circ} \mathrm{C}$ after ESR, (c) $400^{\circ} \mathrm{C}$ without ESR, and (d) $400^{\circ} \mathrm{C}$ after ESR.

the bainitic ferrites are the main contributing factors controlling the strength properties. The higher volume fraction of thinner bainitic ferrites would result in higher strength values. Considering finer bainitic ferrites in combination with more uniform size distribution both make it logical to gain higher UTS in ESR samples. However, samples austempered at $400{ }^{\circ} \mathrm{C}$ gave higher strength values despite their thicker bainitic ferrites which can be attributed to their higher volume fraction of martensite within the microstructure. This is in good agreement with hardness variations as it has been demonstrated before. On the other hand, the lower volume fraction of high carbon retained austenite in both ESR and non-ESR samples at $400{ }^{\circ} \mathrm{C}$ makes it reasonable to obtain lower elongation results. However, applying the ESR process could increase the elongation in both sets of samples because of the higher content of austenite. On the other hand, it has been shown that higher mechanical stability of austenite is mandatory to gain higher elongation and improved strength-ductility properties $[34,36]$. It seems that reduced segregation degree and more uniform distribution of alloying elements in combination with lower inclusions content all enhanced the mechanical stability of retained austenite and resulted in a much beneficial TRIP effect occurrence while straining

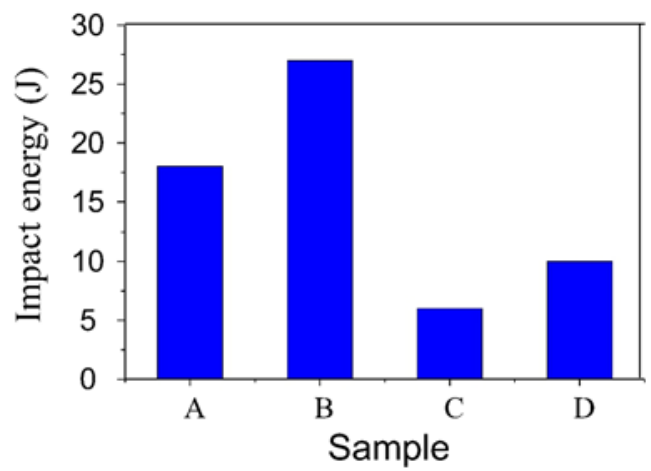

Fig. 9. Charpy impact energy for samples austempered at $350{ }^{\circ} \mathrm{C}$ (A: without ESR), $350^{\circ} \mathrm{C}$ (B: after ESR), $400^{\circ} \mathrm{C}(\mathrm{C}$ : without ESR), and $400^{\circ} \mathrm{C}$ (D: after ESR).

the samples. Therefore, it was convincible to achieve much improved comprehensive mechanical properties after conducting the ESR process.

Figure 8 depicts the fracture surfaces of the tensile test samples. It approves the previous quantitative ductility data, and it can be seen that the samples with higher elongation possessed a much ductile fracture mode, i.e., more and larger dimples along with few fracture facets. 

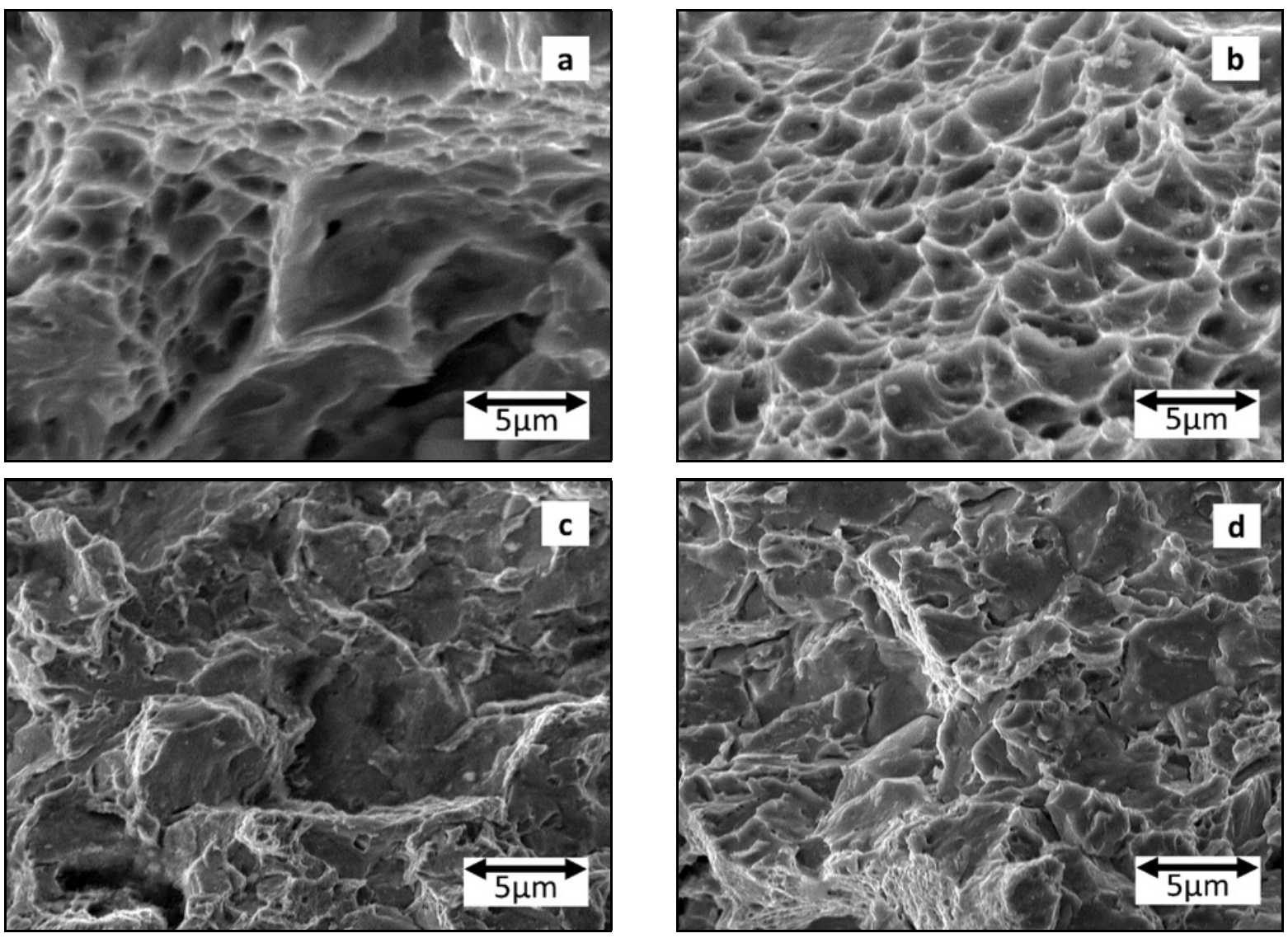

Fig. 10. Fracture surfaces of impact test specimens austempered at (a) $350{ }^{\circ} \mathrm{C}$ without ESR, (b) $350{ }^{\circ} \mathrm{C}$ after $\mathrm{ESR},(\mathrm{c})$ $400^{\circ} \mathrm{C}$ without ESR, and (d) $400^{\circ} \mathrm{C}$ after ESR.

Figure 9 illustrates the impact toughness energy changes at each heat treatment condition. Results indicated that, similar to elongation changes, samples austempered at $350^{\circ} \mathrm{C}$ had higher impact toughness comparing to that of isothermal heat-treated at $400^{\circ} \mathrm{C}$ in both ESR and non-ESR samples. It is also evident that conducting the ESR process successfully improved the impact toughness in both austempering temperatures. These variations are more sensible when studying the fracture surfaces of impact test specimens as it has been shown in Fig. 10, where it can be seen that samples with higher impact toughness had more ductile fracture mode similar to that observed at the fracture surfaces of the tensile test samples.

Presence of higher amount of martensite within the microstructure of the samples austempered at $400{ }^{\circ} \mathrm{C}$ caused these materials to be more brittle in comparison to those isothermal heat-treated at $350{ }^{\circ} \mathrm{C}$ in both ESR and non-ESR conditions. Higher fracture facets in Fig. 10 were generated in these martensitic regions. Better impact toughness can be attributed to the higher amount of austenite within the microstructure in samples austempered at $350^{\circ} \mathrm{C}$ and also in ESR samples. Austenite is a ductile phase which is the main contributing factor controlling the ductility.
In addition to its high volume fraction, it must be mechanically stable enough to resist the crack growth and to blunt the crack propagation during the impact test. So it is not strange to gain better toughness performance in ESR samples due to the higher amount of austenite and also its higher mechanical stability. As it has been mentioned before, reduced segregation improves the mechanical stability of austenite, and it would take its advantageous role in toughness promotion. Finally, it must be mentioned that lower content of inclusions in ESR samples also promotes the toughness and ductility properties since they could act as potential nucleation sites for cracks during deformation which in turn would decrease the toughness and ductility.

\section{Conclusions}

The effect of a primary ESR process was investigated on microstructural characteristics, and comprehensive mechanical properties in a carbide free bainitic steel with chemical composition $0.24 \mathrm{C}-1.45 \mathrm{Si}-0.58 \mathrm{Mn}-$ $-1.1 \mathrm{Cr}-0.25 \mathrm{Mo}-0.98 \mathrm{Cu}-0.13 \mathrm{~V} 0.047 \mathrm{Al}$ (wt.\%) isothermally austempered at 350 and $400^{\circ} \mathrm{C}$. It has been demonstrated that conducting the ESR process was 
essential to promote the quality of the primary cast material. It could be beneficial to decrease the number of inclusions and produce a more uniform microstructure. Conducting the ESR process decreased the average thicknesses of the bainitic ferrites from 0.190 to $0.169 \mu \mathrm{m}$ for samples austempered at $350^{\circ} \mathrm{C}$ and from 0.288 to $0.272 \mu \mathrm{m}$ for samples austempered at $400^{\circ} \mathrm{C}$. It has increased the volume fraction of austenite from 9 to $16 \%$ and from less than 5 to about $5 \%$ for samples austempered at 350 and $400{ }^{\circ} \mathrm{C}$, respectively. ESR process also resulted in mechanically and thermally more stable austenite. These microstructural features positively influenced the strength and ductility properties. The increased austenite contents after ESR and enhanced properties are indicative of reduced segregation of alloying elements and the homogeneity of the microstructure. Conducting a primary ESR increased the tensile strength for about $65 \mathrm{MPa}$ and $100 \mathrm{MPa}$ for samples austempered at 350 and $400{ }^{\circ} \mathrm{C}$, respectively, and the percent elongation increased about $2 \%$ for samples of both austempering temperatures. Charpy impact toughness also improved after ESR for about 4 and $9 \mathrm{~J}$ at austempering temperatures of 350 and $400^{\circ} \mathrm{C}$, respectively.

\section{Acknowledgement}

Authors are acknowledging the Sahand University of Technology for providing the research facilities.

\section{References}

[1] Donachie, M. J., Donachie, S. J.: Superalloys: A Technical Guide. Materials Park, ASM International 2002.

[2] Medovar, B. I.: Electroslag Remelting. Army Foreign Science and Technology Center, Charlottesville 1974.

[3] Lizhong, C., Xiaofang, S., Runxi, W., Junqiang, C., Tao, L.: China Foundry, 11, 2014, p. 452.

[4] Kawalla, R.: ISIJ International, 46, 2006, p. 1361. doi:10.2355/isijinternational.46.1361

[5] Wang, Q.: China Foundry, 4, 2014, p. 018.

[6] Chiniforush, E. A., Iranipour, N., Yazdani, S.: China Foundry, 13, 2016, p. 217. doi:10.1007/s41230-016-6034-6

[7] Beeley, P. R.: The Hatfield Memorial Lectures. Cambridge, Woodhead Publishing, 2005.

[8] Dong, T.-S., Liu, J.-H., Fang, Q., Li, G.-L., Zhang, J.J.: China Foundry, 13, 2016, p. 389 doi:10.1007/s41230-016-6049-z

[9] Jinchun, S., Changzhou, W., Song, L.: Research \& Development, 11, 2014, p. 163.

[10] Presoly, P., Korp, J., Schneider, R.: Archives of Metallurgy and Materials, 53, 2008, p. 567.

[11] Plöckinger, E.: Electroslag Remelting - A Modern Tool in Metallurgy, The Hatfield Memorial Lectures. Cambridge, Woodhead Publishing Limited 1972.

[12] Jiang, Z. H., Yu, J., Liu, F. B., Chen, X., Geng, X.: High Temperature Materials and Processes, 36, 2017, p. 411. doi:10.1515/htmp-2016-0146
[13] Pribulová, A., Futáš, P., Kmita, A., Márasová, D., Holtzer, M.: Archives of Metallurgy and Materials, 62, 2017, p. 181. doi:10.1515/amm-2017-0025

[14] Qi, Y.-F., Li, J., Shi, C.-B., Zhang, Y., Zhu, Q.-T., Wang, H.: Journal of Materials Processing Technology, 249, 2017, p. 32. doi:10.1016/j.jmatprotec.2017.05.034

[15] Fu, R., Li, F., Yin, F., Feng, D., Tian, Z., Chang, L.: Materials Science and Engineering: A, 638, 2015, p. 152. doi:10.1016/i.msea.2015.04.068

[16] Hebsur, M. G., Abraham, K., Prasad, Y.: Engineering Fracture Mechanics, 13, 1980, p. 851. doi:10.1016/0013-7944(80)90016-8

[17] Pacyna, J.: Steel Research International, 57, 1986, p. 586. doi:10.1002/srin.198600830

[18] Bhadeshia, H. K. D. H., Garcia-Mateo, C., Brown, P.: Bainite Steel and Methods of Manufacture Thereof. Patent no. GB2462197. 2010.

[19] Garcia-Mateo, C., Caballero, F. G.: Handbook of Mechanical Nanostructuring. Hoboken, John Wiley \& Sons, Inc. 2015. doi:10.1002/9783527674947.ch3

[20] Caballero, F. G., Bhadeshia, H. K. D. H., Mawella, K. Jones, D., Brown, P.: Materials Science and Technology, 17, 2001, p. 512. doi:10.1179/026708301101510348

[21] Caballero, F., Bhadeshia, H., Mawella, K., Jones, D., Brown, P.: Materials Science and Technology, 17, 2001, p. 517. doi:10.1179/026708301101510357

[22] Soliman, M., Palkowski, H.: Archives of Civil and Mechanical Engineering, 16, 2016, p. 403. doi:10.1016/j.acme.2016.02.007

[23] Yoozbashi, M., Yazdani, S., Wang, T.: Materials \& Design, 32, 2011, p. 3248. doi:10.1016/j.matdes.2011.02.031

[24] Avishan, B., Yazdani, S., Caballero, F., Wang, T., Garcia-Mateo, C.: Materials Science and Technology, 31,2015 , p. 1508 doi:10.1179/1743284714Y.0000000745

[25] Golchin, S., Avishan, B., Yazdani, S.: Materials Science and Engineering A, 656, 2016, p. 94. doi:10.1016/j.msea.2016.01.025

[26] Avishan, B., Tavakolian, M., Yazdani, S.: Materials Science and Engineering A, 693, 2017, p. 178. doi:10.1016/j.msea.2017.03.104

[27] Cullity, B. D., Stock, S. R.: Elements of X-Ray Diffraction. New York, Prentice Hall 2001.

[28] Chang, L. C., Bhadeshia, H. K. D. H.: Materials Science and Technology, 11, 1995, p. 874. doi:10.1179/mst.1995.11.9.874

[29] Singh, S. B., Bhadeshia, H. K. D. H.: Materials Science and Engineering A, 245, 1998, p. 72. doi:10.1016/S0921-5093(97)00701-6

[30] Bhadeshia, H. K. D. H.: Materials Algorithms Project. https://www.phase-trans.msm.cam.ac.uk/map/ backg.html

[31] Bhadeshia, H. K. D. H.: Bainite in Steels. $2^{\text {nd }}$ Edition. London, Institute of Materials 2001.

[32] Ławrynowicz, Z., Barbacki, A.: Advances in Materials Science, 2, 2002, p. 5

[33] Fang, H.-S., Yang, J.-B., Yang, Z.-G., Bai, B.-Z. Scripta Materialia, 47, 2002, p. 157. doi:10.1016/S1359-6462(02)00122-7

[34] Avishan, B., Yazdani, S., Nedjad, S. H.: Materials Science and Engineering: A, 548, 2012, p. 106. 
doi:10.1016/j.msea.2012.03.098

[35] Avishan, B., Garcia-Mateo, C., Morales-Rivas, L., Yazdani, S., Caballero, F. G.: Journal of Materials Science, 48, 2013, p. 6121. doi:10.1007/s10853-013-7408-4
[36] Avishan, B., Garcia-Mateo, C., Yazdani, S., Caballero, F. G.: Materials Characterization, 81, 2013, p. 105. doi:10.1016/j.matchar.2013.04.015 